\title{
Environmental-Economic Assessment of the Pressure Swing Adsorption Biogas Upgrading Technology
}

\author{
Norbert Kohlheb $^{1}$ (D) - Mathias Wluka ${ }^{2}$ - Alberto Bezama ${ }^{1}$ (D) Daniela Thrän ${ }^{1,3}$ (D) Andreas Aurich ${ }^{1}$. \\ Roland Arno Müller ${ }^{1}$
}

Received: 12 July 2020 / Accepted: 12 October 2020 / Published online: 24 October 2020

(C) The Author(s) 2020

\begin{abstract}
A large-scale biogas upgrading plant using the CarboTech® technology with a treatment capacity of $1333 \mathrm{Nm}^{3}$ biogas per hour was analyzed. Our scope of evaluation encompasses all technology steps that are necessary for upgrading biogas, i.e., both pretreatment and biogas upgrade. A cradle-to-gate life-cycle and life-cycle cost assessment (LCA and LCCA) methodology was used with the functional unit (FU) of $1 \mathrm{Nm}^{3}$ of biogas upgraded in order to ease comparison with other biogas upgrading technologies. The calculation was made using the GaBi8 LCA software and databases of GaBi Professional, Construction materials, Food\&Feed, and the ecoinvent3. We applied the CML characterization model with all its mid-point indicators. The mid-point indicators of the CML characterization model were aggregated after normalization by the CML2001 - Jan.2016 normalization factors. The normalized environmental impact was $541.74 \cdot 10^{-15} / \mathrm{Nm}^{3}$ raw biogas. The highest environmental impacts were the marine aquatic ecotoxicity potential $\left(15.705 \mathrm{~kg}\right.$ dichlorobenzene-equiv. $/ \mathrm{Nm}^{3}$ raw biogas), the abiotic depletion potential (1.037 MJ/ $\mathrm{Nm}^{3}$ raw biogas), and global warming potential (0.113 $\mathrm{kg} \mathrm{CO}_{2}$-equiv. $/ \mathrm{Nm}^{3}$ raw biogas). The unit production cost of the PSA technology was $0.05-0.063 € / \mathrm{Nm}^{3}$ raw biogas. The most considerable source of expenses was the operational cost from which $77 \%$ was spent on electricity. The initial investment, personal costs, and the reinvestment amounted to only $34 \%$ of the total costs for the whole life cycle. Strategies to lower the environmental burden of the PSA technology are to use green electricity and to optimize the size of the plant in order to reduce unnecessary material flows of building material and their indirect energy use. This can also lower investment expenditures while automatization and remote control may spare personnel costs.
\end{abstract}

Keywords Biogas upgrading · Pressure swing adsorption · Life-cycle sustainability assessment

\section{Introduction}

Renewable energy has a major role to play in combating climate change and establishing a more sustainable way of living $[1,2]$. Bioenergy, and the anaerobic digestion within it, are

Electronic supplementary material The online version of this article (https://doi.org/10.1007/s12155-020-10205-9) contains supplementary material, which is available to authorized users.

Norbert Kohlheb

norbert.kohlheb@ufz.de

1 Helmholtz Centre for Environmental Research, Permoserstr. 15, 04318 Leipzig, Germany

2 eins energie in sachsen GmbH \& Co. KG, P.B. 411468 , 09030 Chemnitz, Germany

3 Deutsches Biomasseforschugszentrum gGmbH - DBFZ, Torgauer Str. 116, 04347 Leipzig, Germany important constituents of a sustainable energy mix in Europe $[3,4]$. Anaerobic digestion is a complex bio-chemical transformation process mainly under anaerobic conditions done by a mixture of aerobic and anaerobic microorganisms, such as fermentative and methanogenic bacteria, and produces biogas $[5,6]$. Biogas, usually having a variable composition of $\mathrm{CH}_{4}$ and $\mathrm{CO}_{2} 35-70 \%$ and $15-40 \%$, respectively [4, 7], can be used in versatile ways having less problems of use, such as low energy density, emissions, and corrosion when upgraded, and performs similar characteristics as natural gas $[3,4,8,9]$.

Between 2011 and 2017, biogas production in the EU increased from 123,526 to $195,684 \mathrm{GWh}$ [10]. Although the majority of biogas is used for electricity (62\%) and heat (27\%) production [5, 11], the amount of upgraded biogas grew from 752 to $22,048 \mathrm{GWh}$ [12]. This is almost a thirtyfold growth that indicates a shift of the business model of biogas plants, from electricity and heat production to upgrading biogas to biomethane [3]. During the earlier development of the biogas upgrading technology, water scrubbing 
(WS) and pressure swing adsorption (PSA) were the dominating technologies $[4,13]$. Since then, a wider range of physical/ chemical technologies have become available on the market, such as organic solvent or chemical scrubbing, cryogenic or membrane separation, as well as physical and chemical adsorption $[4,7,13-15]$. As these technologies offer also competitive prices, the market situation has changed, and the previous domination of PSA and WS has diminished, leading to a much more balanced situation [4].

Despite being the most widely used, reliable, and established technology commercially available in multiple scales where much experience is available $[13,16$, 17], the PSA technology still has some drawbacks, e.g., it needs a two-stage process to remove $\mathrm{CO}_{2}$ and $\mathrm{H}_{2} \mathrm{~S}$, can have rather high methane slips and requires a high pressure $[13,14,16,18]$, and, consequently, have a high global warming potential (GWP) of $83.6-85.3 \mathrm{~kg} \mathrm{CO}_{2^{-}}$ equiv./100 $\mathrm{Nm}^{3}$ biomethane [19]. On the other hand, PSA is competitive in price $\left(0.064-0.13 € / \mathrm{Nm}^{3}\right.$ biogas) and cleaning level and can eliminate both oxygen and ammonium together with $\mathrm{CO}_{2}[13,14,18,20]$. Thus, the PSA technology is very much suited for being a basis for comparison for newly developed biogas upgrading technologies.

Nonetheless, the development of new technologies for biogas upgrading has not stopped, and the search for more advanced technologies that allow the establishment of efficient and sustainable supply chains that could couple the biogas system in the bio-based economy is currently of utmost importance [21]. Life-cycle assessment (LCA) is a valuable tool that is often used to analyze evolving technologies and their bottlenecks creating more sustainable ways. Studies assessing sustainability of biogas upgrading technologies are not just limited in number $[4,5,7,9,19$, 22-24], but they also differ in terms of the evaluated technology, scope, applied data base, functional unit (FU), and characterization model, which hinder comparison and further analysis. In addition, many studies consider only major operational energy and material consumption and base their calculations on literature or modeling data. To the best of our knowledge, there are no studies available in the literature that analyze a mainstream biogas upgrading technology, such as pressure swing adsorption (PSA) based on empirical data from a functioning full-scale biogas upgrading plant. This study addresses this knowledge gap and focuses on the lifecycle assessment of the PSA technology using empirical data from a functioning full-scale plant. The results obtained from this assessment are therefore helpful to provide a reference system for comparison with other technologies.

In the next sections, we describe our methodology of analysis and introduce the analyzed PSA plant. Finally, the results are presented and discussed, comparing them with the outcomes of previously published studies.

\section{Methods}

\section{Description of the PSA Biogas Upgrading Technology}

The biogas upgrading plant, with a treatment capacity of $1333 \mathrm{Nm}^{3}$ biogas per hour, i.e., $32,000 \mathrm{Nm}^{3}$ biogas per day, is located in Brandis, Saxony, Germany, and was built in 2013 using the CarboTech ${ }^{\circledR}$ technology.

The composition of input and output gases is given in Table 1. The relatively low concentration of $\mathrm{H}_{2} \mathrm{~S}$ is due to the energy crop-based feedstock (59\% maize silage, 10-15\% grass silage, $10-15 \%$ wholecrop cereal silage, $5-12 \%$ sugar beet, and $1 \%$ cereal corn) that could allow to omit the biobased hydrogen sulfur removal. Due to the same reason, siloxane and ammonia were negligible too [14, 25-27]. The biogas plant producing the biogas for the upgrading plant runs between mesophilic $\left(38^{\circ} \mathrm{C}\right)$ and thermophilic $\left(58^{\circ} \mathrm{C}\right)$ conditions due to a missing cooling capacity in the summer and has a total feed-stock need of 52,000 t/a.

The size of the biogas upgrading plant was defined along the renewable energy subsidy scheme given at that time (EEG 2012) that gave the highest subsidy $(3.0 € \mathrm{ct} / \mathrm{kWh}$ of fed-in thermal energy) to plants having a nominal capacity of $700 \mathrm{Nm}^{3} / \mathrm{h}$ biomethane. This corresponds to a biogas input of $1400 \mathrm{Nm}^{3} / \mathrm{h}$ [13].

Our scope of evaluation encompasses all technology steps that are necessary for upgrading biogas. These steps are grouped in two sections: pretreatment and biogas upgrading (see also Fig. 1). The pretreatment step consists of $\mathrm{H}_{2} \mathrm{~S}$ and water removal; meanwhile the biogas upgrading phase cleans the biogas from carbon dioxide, oxygen, and the rest of ammonium. In the pretreatment phase, the biogas stream is first led to the biotrickling filter to remove $\mathrm{H}_{2} \mathrm{~S}$ (Bio- $\mathrm{H}_{2} \mathrm{~S}$ removal). Since $\mathrm{H}_{2} \mathrm{~S}$ is irreversibly captured by the adsorbent material in the PSA unit, $\mathrm{H}_{2} \mathrm{~S}$ removal has to be placed before the PSA step $[13,14,16,18,28]$. In the biotrickling filter, aerobic bacteria decompose $\mathrm{H}_{2} \mathrm{~S}$, and to keep these bacteria in the

Table 1 Composition of biogas and upgraded biomethane

\begin{tabular}{lll}
\hline & Input & Output in Brandis \\
\hline $\mathrm{CH} 4, \%$ & $51.4-52.2$ & 96 \\
$\mathrm{CO}_{2}, \%$ & $45-47$ & 3.5 \\
$\mathrm{O}_{2}, \%$ & 0.05 & n.a. \\
$\mathrm{H}_{2} \mathrm{O}, \%$ & $1-2$ & n.a. \\
$\mathrm{H}_{2}, \mathrm{ppm}$ & 72 & n.a. \\
$\mathrm{H}_{2} \mathrm{~S}, \mathrm{ppm}$ & 55 & 1 \\
\hline
\end{tabular}




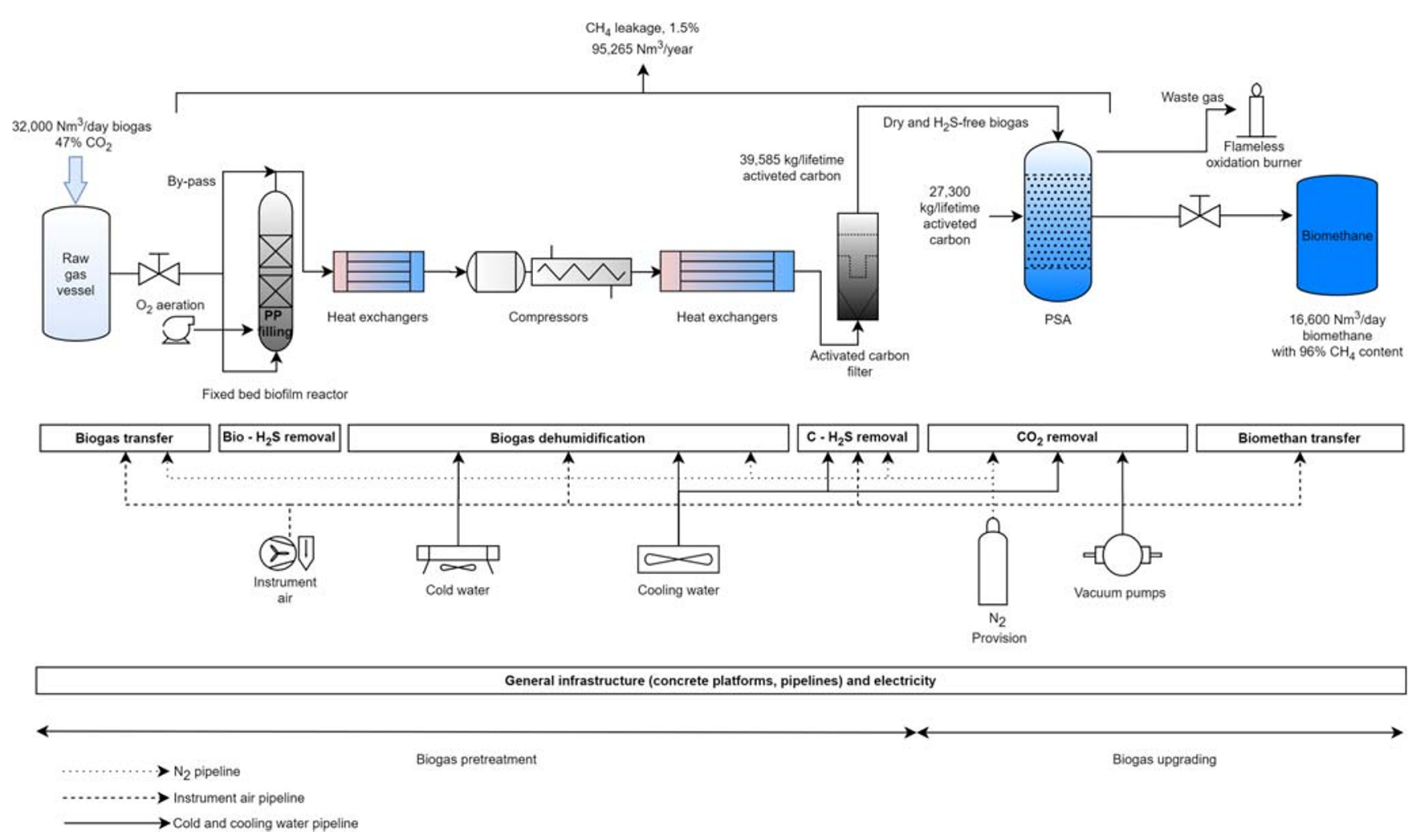

Fig. 1 Process flow of the PSA biogas upgrade technology

reactor, an enlarged surface polyethylene carrier is placed inside the reactor (see Table S1 in the Supplementary material for details). However, because of the very low concentration of $\mathrm{H}_{2} \mathrm{~S}$ in the input biogas at this PSA plant no sulfur sludge was produced. Consequently, no discharge of sludge and no extra input of alkali reagent, such as $\mathrm{NaOH}$, were considered for the biotrickling filter. In addition, by-passing the biotrickling filter became a real alternative worth reexamining.

The pretreatment process continues with the biogas transfer directly from the biogas reactor or the biotrickling filter through the first chiller. Then the biogas stream is compressed and chilled again for further dehumidification (biogas dehumidification). The pretreatment ends with an activated carbon filter where residues of $\mathrm{H}_{2} \mathrm{~S}$ can be filtered out $\left(\mathrm{C}-\mathrm{H}_{2} \mathrm{~S}\right.$ removal) together with other possible contaminants such as siloxanes, nitrogen, ammonium, and oxygen, if they are present in the gas [4]. This is a secondary, so-called fine desulfurization step to protect the next unit from contamination [13]. In the upgrading phase, the dry and $\mathrm{H}_{2} \mathrm{~S}$-free biogas is led to the PSA unit where $\mathrm{CO}_{2}$ is temporally adsorbed to activated carbon in order to separate it from methane $\left(\mathrm{CO}_{2}\right.$ removal), which is then stored and transferred to the natural gas pipeline (biomethane transfer). Next, the pressurized (at 6 bar) PSA vessel is regenerated using vacuum $(-0.85$ bar) to release the carbon dioxide from the adsorbent (see the pressure regime of PSA vessel in Fig. S5), along with a small fraction of methane present in this gas. This gas mixture is called waste gas and is burned with a flameless oxidation burner to avoid methane emission from the plant. However, the majority of environmental burdens, i.e., GWP and photochemical ozone creation potential (POCP), are associated to the methane losses being 3.5-4\% of total methane treated [19, 23], and the $\operatorname{CarboTech}{ }^{\circledR}$ technology guarantees a methane slip less than $2 \%$ [13]. In addition, in Germany a low level of $\mathrm{CH}_{4}$ leakage $(\max 0.2 \%)$ is a prerequisite for renewable energy subsidy [20]. Based on the information provided by the operator of the biogas plant, we considered $0.2 \%$ methane emission to the air of the total methane treated in the PSA plant, i.e., $12,194 \mathrm{Nm}^{3}$ methane/year.

The flameless oxidation process is considered to be an autothermic burning [13], so crediting recuperated heat for heating the biogas plant was not possible. The steps of the PSA technology are depicted in Fig. 1.

The electricity consumption of the PSA plant was recorded only as a total for the whole plant, i.e., 2,568,985 kWh/year, giving a mean specific electricity consumption of $0.22 \mathrm{kWh} /$ $\mathrm{Nm}^{3}$ biogas. It was not possible to measure the electricity consumption separately for every unit, and so it could not be divided among the different units within the PSA plant. Although it can be assumed that compression and cooling of biogas together consume the highest proportion of electricity [13]. 
Beside the above listed main technological steps, supplementary modules such as general infrastructure, instrument air, cooling water, nitrogen provision, cold water, and electricity were also considered. The inventory of these steps is given in the Supplementary material (Table S1).

\section{Description of the Assessment Methodology}

The total life cycle of the PSA plant was set to 20 years. Within this period, the plant can purify $32,000 * 365 * 20 \mathrm{Nm}^{3}$ biogas, i.e., $233,600,000 \mathrm{Nm}^{3}$, which is our reference flow. From this amount of biogas, 127,020,000 $\mathrm{Nm}^{3}$ biomethane can be produced that was calculated from the methane proportion of raw and upgraded biogas (see in Table 1: 52.2/96). To ease comparison with other biogas upgrading technologies, the functional unit (FU) was set to $1 \mathrm{Nm}^{3}$ of biogas upgraded. A cradle-to-gate life-cycle and life-cycle cost assessment (LCA and LCCA) of the above described PSA biogas upgrading plant were carried out.

The goal and scope, inventory development, and impact assessment of the LCA were defined and accomplished according to the ISO 14040:2006 standard, using GaBi8 LCA software and the $\mathrm{GaBi}$ databases Professional, Construction materials, Food\&Feed, and the ecoinvent 3 database. We used the CML characterization model with all its mid-point indicators. The results were divided by the references flow $\left(233,600,000 \mathrm{Nm}^{3}\right.$ biogas treated/lifetime), i.e., the total biogas treated per lifetime of the plants, to gain comparable results. The mid-point indicators of the CML characterization model were aggregated after normalization by the CML2001 Jan.2016 normalization factors.

Data about the operating PSA plant in Brandis were collected based on the planning documentation, shop drawings, the commissioning documentation, and by visiting the plant. The transformation of these data to the LCA inventory was made by following the decision tree given in Fig. 2. When only the weight of the major composition was possible to define, e.g., steel or plastic, the manufacturing activity was also accounted for, such as metal working or blow molding. However, these data deteriorated the accuracy of the calculation.

For the LCCA, the initial investment, reinvestment, operation, personnel, and maintenance costs for the entire life cycle of the PSA technology from planning and operational data of the PSA biogas upgrading plant were collected. The economic performance was assessed using the LCC framework with a total life cycle of 20 years. The cost of electricity was set to $0.17 € / \mathrm{kWh}$ and the personal cost $80,000 € /$ year. We used a discount rate of $2.7 \%$ [29] to calculate dynamic economic indicators, such as capital expenditures (CAPEX), operational expenditures (OPEX), present value (PV) [30], and unit production cost (UPC).

The CAPEX was calculated using Eq. (1):

CAPEX $=$ initial investment $+\sum \mathrm{RI}_{\text {biofilter }}+\sum \mathrm{RI}_{\mathrm{PSA}}+\sum \mathrm{RI}_{\text {comp }}+\sum \mathrm{RI}_{\mathrm{v} \text {-pump }}$

where:

$\begin{array}{ll}\mathrm{RI}_{\text {biofilter }} & \begin{array}{l}\text { discounted reinvestment of biotrickling filter per } \\ \text { year }\end{array} \\ \mathrm{RI}_{\text {PSA }} & \begin{array}{l}\text { discounted reinvestment of PSA carbon filter and } \\ \text { pressure containers per year } \\ \text { discounted reinvestment of compressors per year } \\ \mathrm{RI}_{\text {comp }}\end{array} \\ \mathrm{RI}_{\mathrm{v} \_ \text {pump }} & \begin{array}{l}\text { discounted reinvestment of vacuum pumps per } \\ \text { year }\end{array}\end{array}$

The calculation of OPEX was made according to Eq. (2): $\mathrm{OPEX}=\frac{\sum \mathrm{MC}_{\text {biofilter }}+\sum \mathrm{MC}_{\mathrm{PSA}}+\sum \mathrm{MC}_{\text {comp }}+\sum \mathrm{MC}_{\mathrm{v} \text {-pump }}+\sum \mathrm{C}_{\text {power }}+\sum \mathrm{C}_{\text {personal }}}{\text { life span of plant }}$

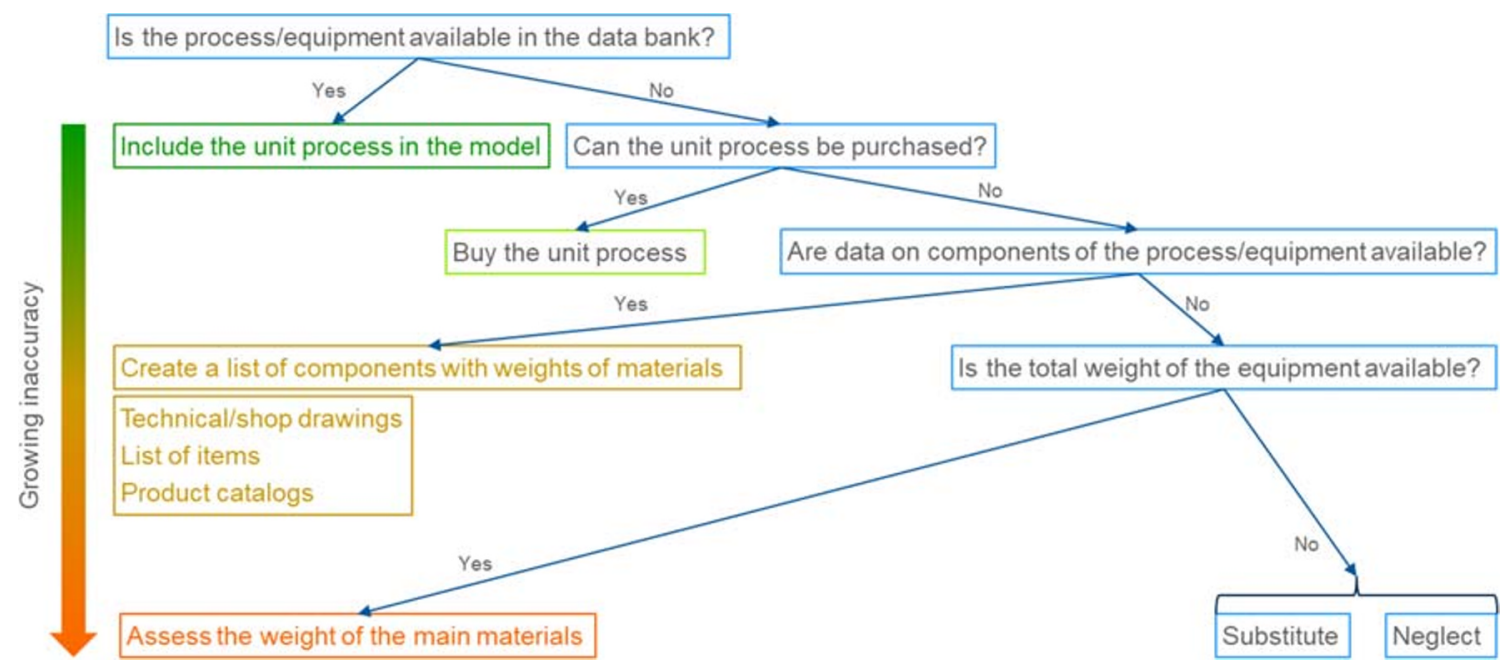

Fig. 2 Decision tree for dealing with data gaps in life cycle inventories 
where:

$\begin{array}{ll}\mathrm{MC}_{\text {biofilter }} & \begin{array}{l}\text { discounted maintenance costs of biotrickling } \\ \text { filter per year } \\ \text { discounted maintenance costs of PSA carbon } \\ \text { filter and pressure containers per year } \\ \mathrm{MC}_{\mathrm{PSA}}\end{array} \\ \mathrm{MC}_{\text {comp }} & \begin{array}{l}\text { discounted maintenance costs of compressors } \\ \text { per year } \\ \text { discounted maintenance costs of vacuum pumps }\end{array} \\ \mathrm{MC}_{\mathrm{v} \_ \text {pump }} & \begin{array}{l}\text { per year } \\ \text { discounted power costs per year } \\ \mathrm{C}_{\text {power }}\end{array} \\ \mathrm{C}_{\text {personal }} & \text { discounted personal costs per year }\end{array}$

The present value was discounted using the discount factor as calculated in Eq. (3).

Discount factor $=\frac{1}{(1+i)^{t}}$

where:

i discount rate

$t$ actual year when the cost emerged

PV was calculated according to Eq. (4).

$\mathrm{PV}=\sum C_{t} \cdot \frac{1}{(1+i)^{t}}=\mathrm{CAPEX}+\mathrm{OPEX} \cdot n$

where:

$C_{t} \quad$ total cost per year

$n \quad$ life span of facility

UPC was calculated by dividing PV by the reference flow, i.e., the total amount of biogas cleaned during the lifetime of the plant $\left(233.6\right.$ million $\left.\mathrm{Nm}^{3}\right)$.

\section{Results}

\section{Environmental Impacts of the PSA Technology}

The PSA biogas upgrading plant has its highest environmental impacts in marine aquatic ecotoxicity potential (MAETP), abiotic depletion potential (ADP), and GWP, as given in italics in Table 2. The main source of these impacts stems from $\mathrm{CH}_{4}$ leakage and electricity consumption (EU-28 electricity mix), while other sources have an impact of two or three orders of magnitude less. In the electricity consumption, the main impact flow for MAETP was the hydrogen fluoride emission, ${ }^{1}$ for ADP it was hard coal, natural gas, and lignite consumption, and for GWP, the $\mathrm{CO}_{2}$ and $\mathrm{N}_{2} \mathrm{O}$ emission were the major impact flows. When neglecting $\mathrm{CH}_{4}$ leakage and

\footnotetext{
${ }^{1}$ Hydrogen fluoride is mainly used for manufacturing refrigerants. When dissolved in water, it forms hydrofluoric acid that is used for pickling stainless steel.
}

electricity consumption, the main reason for the high ADP is the intensive use of hard coal for the activated carbon and the crude oil for polypropylene production. In addition, stainless steel production also consumes considerable amounts of coal and crude oil. The high emissions of heavy metals and NMVOC again from steel production resulted in a high human toxicity potential (HTP). The considerable MAETP is induced also by steel manufacturing emitting hydrogen fluoride and heavy metals.

It was also important to show which process step brings about the highest environmental impacts. To calculate this, the results of the different mid-point indicators were aggregated using the normalization factors of CML2001 - Jan. 2016 characterization model. The impact of electricity consumption is great (Fig. 3), as it induces $67 \%$, i.e., $335.98 \cdot 10^{-15}$, of the associated environmental impacts. The second biggest environmental impact is produced by the general infrastructure $\left(38.94 \cdot 10^{-15}\right)$ and the third by $\mathrm{CO}_{2}$ removal $\left(35.25 \cdot 10^{-15}\right)$. The $0.2 \%$ methane leakage is responsible only for $1 \%(5.69$. $10^{-15}$ ) of the normalized emissions. Other environmentally intensive process steps are cold water, cooling water, and biogas dehumidification. Each process step has either a considerable amount of concrete or steel built-in, or material needed for operation, such as glycol for cooling water. These material flows and their indirect energy flows create the environmental impacts. Consequently, properly dimensioned machinery and economical use of material for operation do not just save money but also reduce environmental impacts. The option to bypass the biotrickling filter would not bring about a huge environmental impact saving potential.

\section{Economic Impacts of the PSA Technology}

The most considerable source of expenses was the operational cost $(11,314,549 €)$ from which $77 \%$ was spent on electricity. In comparison, the initial investment $(2,691,625 €)$, personal costs $(1,600,000 €)$, and the reinvestment $(696,000 €)$ took only $34 \%$ of the total costs for the whole life cycle (see Fig. 4, and for details Table S2 in the Supplementary material).

The discounted total capital expenditure (CAPEX) was $3,156,840 €$, and the discounted average operational expenditure (OPEX) amounted to $432,786 € /$ year. In total, for the 20 years of lifetime, OPEX makes nearly $77 \%$ of the total costs. The unit production cost (UPC) was $0.05 € / \mathrm{Nm}^{3}$ biogas treated. When personal costs were not considered, UPC dropped to $0.045 € / \mathrm{Nm}^{3}$ biogas treated.

\section{Discussion}

Since the first LCA studies about biogas upgrading technologies were published just about a decade ago [5], there are not 
Table 2 Results of LCA using the CML2001- Jan.2016 characterization model

Mid-point indicators

Environmental impacts of PSA per $\mathrm{Nm}^{3}$ biogas

CML2001 - Jan. 2016, abiotic depletion (ADP elements)

$0.022 \cdot 10^{-5}$
$103,670.648 \cdot 10^{-5}$
$27.801 \cdot 10^{-5}$
$2.832 \cdot 10^{-5}$
$177.855 \cdot 10^{-5}$
$11,290.846 \cdot 10^{-5}$
$2813.705 \cdot 10^{-5}$
$1,570,555.624 \cdot 10^{-5}$
$0.644 \cdot 10^{-5}$
$2.184 \cdot 10^{-5}$
$23.541 \cdot 10^{-5}$

CML2001 - Jan. 2016, abiotic depletion (ADP fossil)

CML2001 - Jan. 2016, acidification potential (AP)

CML2001 - Jan. 2016, eutrophication potential (EP)

CML2001 - Jan. 2016, freshwater aquatic ecotoxicity pot. (FAETP inf.)

CML2001 - Jan. 2016, global warming potential (GWP 100 years), excl biogenic carbon

CML2001 - Jan. 2016, human toxicity potential (HTP inf.)

CML2001 - Jan. 2016, marine aquatic ecotoxicity pot. (MAETP inf.)

CML2001 - Jan. 2016, ozone layer depletion potential (ODP, steady state)

CML2001 - Jan. 2016, photochem. ozone creation potential (POCP)

$23.541 \cdot 10^{-5}$

so many studies available in this field. In addition, in the literature, there is a great variety in the framework conditions for life-cycle analysis which means different functional units (e.g., 1 or $100 \mathrm{~m}^{3}$ biogas or biomethane, $1 \mathrm{t} \mathrm{CO}_{2}$ removed [5, 19, 23]), different length of life cycles (e.g., with or without biogas production and biomethane injection into the grid), different characterization models with different impact categories (e.g., ReCiPe, CML), and different databases (e.g. ecoinvent or GaBi Professional). This high variety of framework condition, of course, hinders the comparison of results. In addition, many studies used data from the literature or collected them via questionnaires $[4,13,19,23,28]$ and provided a too general description of the evaluated technologies, especially in studies that deal with the comparison of alternative technologies. Consequently, the understanding of the technology and the inventory (e.g., the source of $\mathrm{CH}_{4}, \mathrm{SO}_{2}$, $\mathrm{H}_{2} \mathrm{~S}$, and $\mathrm{CO}_{2}$ emissions) and the possibility of making a thorough analysis of the consecutive technology steps identifying hotspots is very much hampered. In particular, the methane slip is a highly important issue, because it may induce the brunt of GWP. Studies in the literature report on a rather high proportion between 1 and $4 \%[19,23,28]$, but do not discuss how the waste gas flow is treated by the different technologies because methane is not necessary discharged to the environment and had to be accounted as an emission. For example, the PSA technology from CarboTech ${ }^{\circledR}$ uses burners to neutralize the $\mathrm{CH}_{4}$ content of waste gas, and so methane slip drops below $0.2 \%$.

Despite the obstacles mentioned above, we tried to verify our result and made a comparison of the data available in the
Fig. 3 Normalized environmental impact of the process steps with electricity

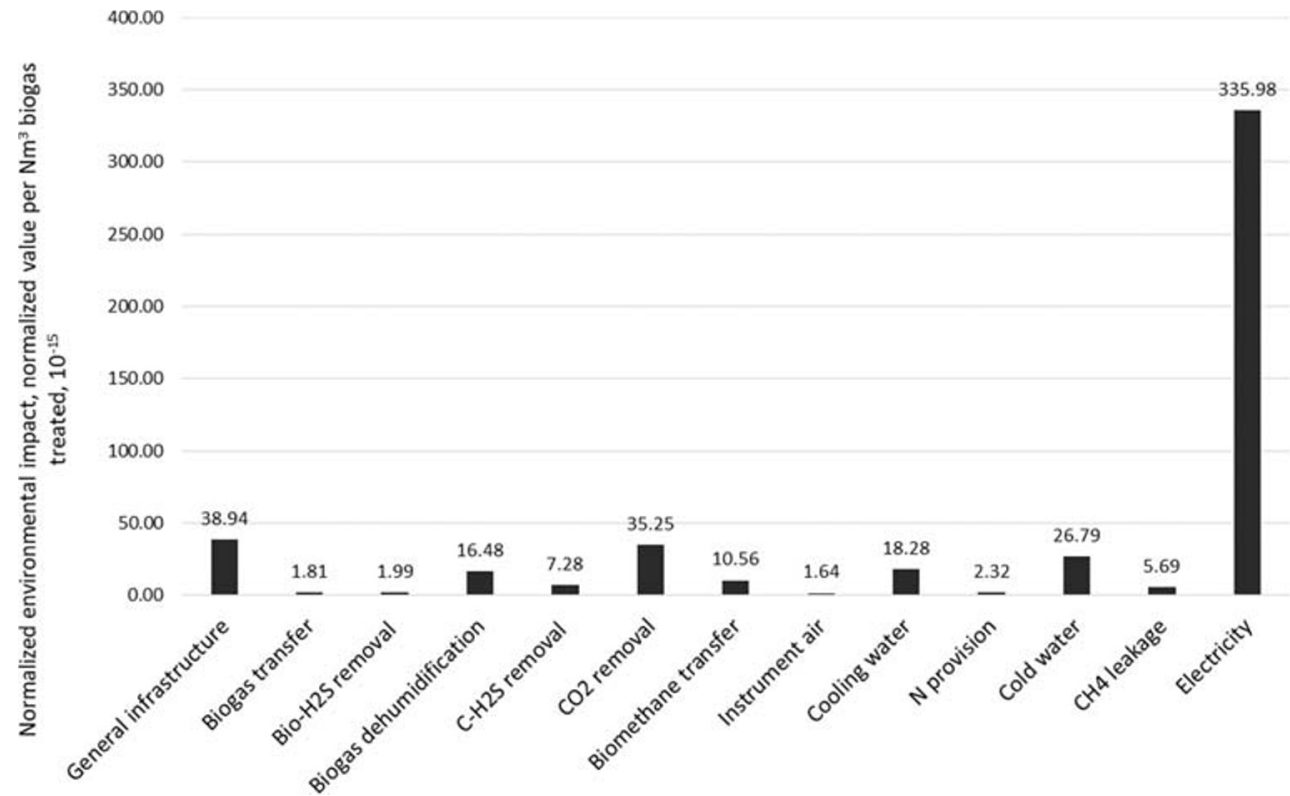



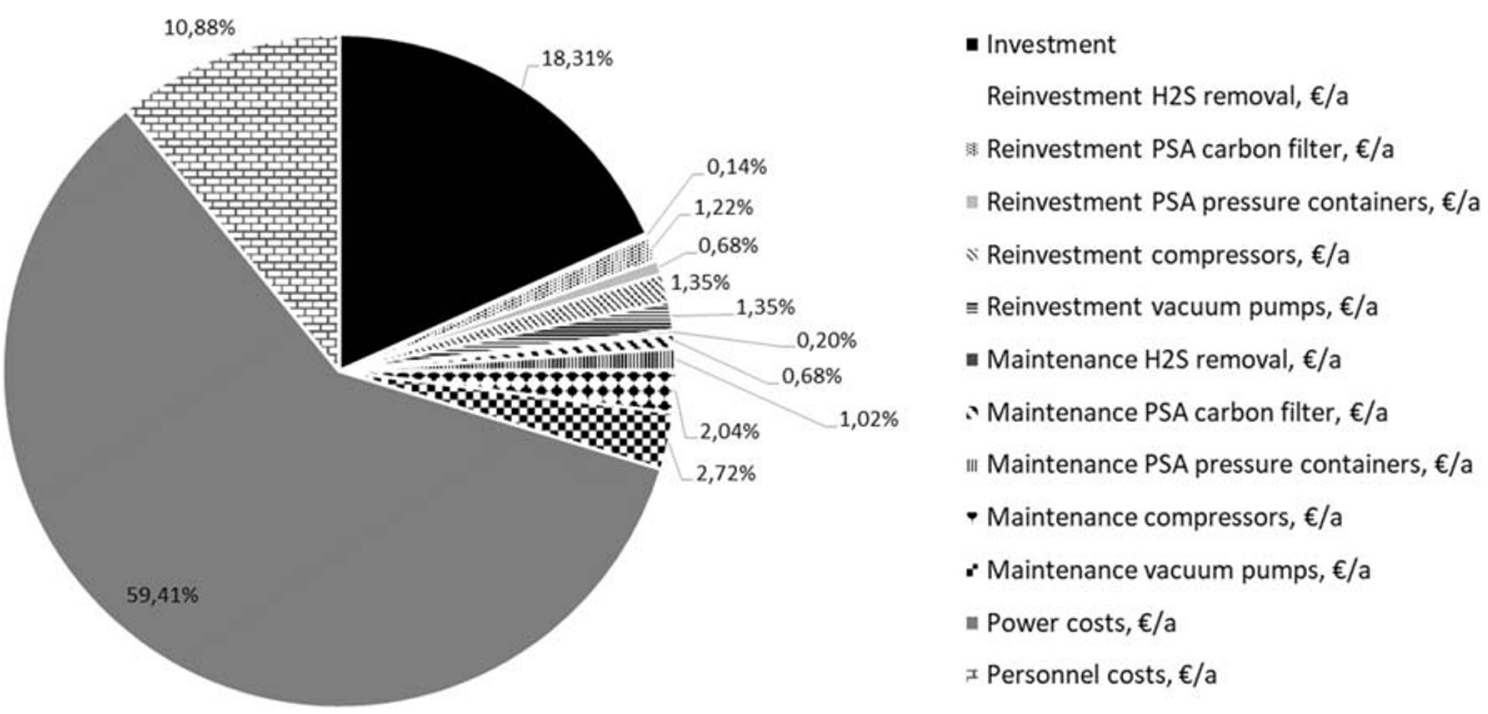

Fig. 4 Cost structure of the PSA plant

literature manly focusing on the electricity consumption and GWP.

The fossil electricity demand of PSA biogas upgrading plants in the literature was reported to be between 0.2 and $0.34 \mathrm{kWh} / \mathrm{Nm}^{3}$ biogas. Pertl et al. (2010) indicated an electricity consumption of $0.72 \mathrm{MJ} / \mathrm{Nm}^{3}$ raw biogas (equals $\left.0.2 \mathrm{kWh} / \mathrm{Nm}^{3}\right)$ that is similar to the data $\left(0.2-0.3 \mathrm{kWh} / \mathrm{Nm}^{3}\right)$ given by Hoyer et al. (2016), but Pertl et al. (2010) added an energy demand for compression and drying of $0.62 \mathrm{MJ} / \mathrm{Nm}^{3}$ upgraded biogas, i.e., $0.097 \mathrm{kWh} / \mathrm{Nm}^{3}$ raw biogas. In this case, the total electricity demand for this technology was ca. $0.3 \mathrm{kWh} / \mathrm{Nm}^{3}$ raw biogas. Florio et al. (2019) revealed a slightly higher electricity consumption: $0.34 \mathrm{kWh} / \mathrm{Nm}^{3}$ biogas. Urban et al. (2009) reported referring to the technology provider $0.25 \mathrm{kWh} / \mathrm{Nm}^{3}$ raw biogas. Although Starr et al. (2012) used a different $\mathrm{FU}$ (ton of $\mathrm{CO}_{2}$ removed), the authors indicated an electricity demand of $915 \mathrm{MJ} / \mathrm{t}$ of $\mathrm{CO}_{2}$ removed, which corresponds to $0.22 \mathrm{kWh} / \mathrm{Nm}^{3}$ raw biogas. Sun et al. (2015) reported electricity consumption values from the literature between 0.23 and $0.3 \mathrm{kWh} / \mathrm{Nm}^{3}$ raw biogas. In our case, the electricity consumption of the total PSA plant was $0.22 \mathrm{kWh} / \mathrm{Nm}^{3}$ raw biogas that is well in the range of the electricity consumption given in the literature. The relatively low value reflects the assumed high capacity $\left(1333 \mathrm{Nm}^{3} / \mathrm{ha}\right)$ of the PSA plant. A $20 \%$ decrease in this capacity would raise the electricity consumption to $0.27 \mathrm{kWh} / \mathrm{Nm}^{3}$ raw biogas.

GWP of PSA technologies is indicated to be between 83.6 and $85.3 \mathrm{~kg} \mathrm{CO}$-equiv. $/ 100 \mathrm{Nm}^{3}$ biomethane [19] which equals to $0.472-0.482 \mathrm{~kg} \mathrm{CO}_{2}$-equiv. $/ \mathrm{Nm}^{3}$ raw biogas. These values are considerably higher than our result for $\operatorname{GWP}\left(0.113 \mathrm{~kg} \mathrm{CO}\right.$-equiv. $/ \mathrm{Nm}^{3}$ raw biogas $)$, mainly because our calculation considered solely $0.2 \% \mathrm{CH}_{4}$ leakage (see "Description of the PSA Biogas Upgrading Technology") and had a lower electricity consumption. When considering $4 \% \mathrm{CH}_{4}$ leakage and an electricity consumption of $0.3 \mathrm{kWh} /$
$\mathrm{Nm}^{3}$ as given in Pertl et al. (2010), our model gains $0.475 \mathrm{~kg}$ $\mathrm{CO}_{2}$-equiv. $/ \mathrm{Nm}^{3}$ raw biogas. This value is much closer to the results of Pertl et al. (2010) and more than fourfold of our original result. This is depicted in Fig. 5. This comparison justifies that considering solely electricity and methane leakage as sources of GWP, they cover more than $95 \%$ of the greenhouse gas emissions form this technology. Nevertheless, other important environmental impacts, such as MAETP, are in this case neglected.

Since electricity is an important source of emissions, we scrutinized how much difference a change in electricity mix can produce. For this, we calculated the environmental impact of the PSA technology when electricity would be produced only from a mixture of wind and solar energy. In this case, GWP drops from 0.113 to $0.031 \mathrm{~kg} \mathrm{CO}$-equiv/ $\mathrm{Nm}^{3}$ biogas treated which is a reduction of more than $70 \%$. Concerning the total environmental impact, it diminishes from $503.00 \cdot 10^{-15}$ to $276.36 \cdot 10^{-15}$ per $\mathrm{Nm}^{3}$ biogas treated which is a reduction of $45 \%$. This switch of power supply would have a considerable economic impact as well. When considering a market price of $0.0433 € / \mathrm{kWh}$ for PV-power and $0.046 € / \mathrm{kWh}$ for onshore wind craft [31] and calculate an average renewable electricity price of $0.045 € / \mathrm{kWh}$, the share of power costs shrinks from 59 to $28 \%$.

The operation and maintenance costs of upgrading technologies reported in the literature are also very different ranging from 0.47 to $6.7 € \mathrm{ct} / \mathrm{kWh}$ biogas [4], which equals to 0.0027 $0.39 € / \mathrm{Nm}^{3}$ biogas, calculated with $5.83 \mathrm{kWh} / \mathrm{Nm}^{3}$ energy content. The upgrading cost of biomethane with the PSA technology was $6.5 € \mathrm{ct} / \mathrm{kWh}$, i.e., $0.38 € / \mathrm{Nm}^{3}$, for a factory with $600 \mathrm{~m}^{3} / \mathrm{h}$ capacity [4]. de Hullu et al. [32] report on total costs between 0.13 and $0.44 € / \mathrm{Nm}^{3}$ where PSA has $0.25 € / \mathrm{Nm}^{3}$. Other sources report much lower costs of 1.4-2.3 $€ \mathrm{ct} / \mathrm{kWh}$ for biogas upgrading [20], i.e., $0.08-0.13 € / \mathrm{Nm}^{3}$ biogas. Very similar numbers to our results were reported by Urban et al. 
Fig. 5 Comparison of own results with the literature

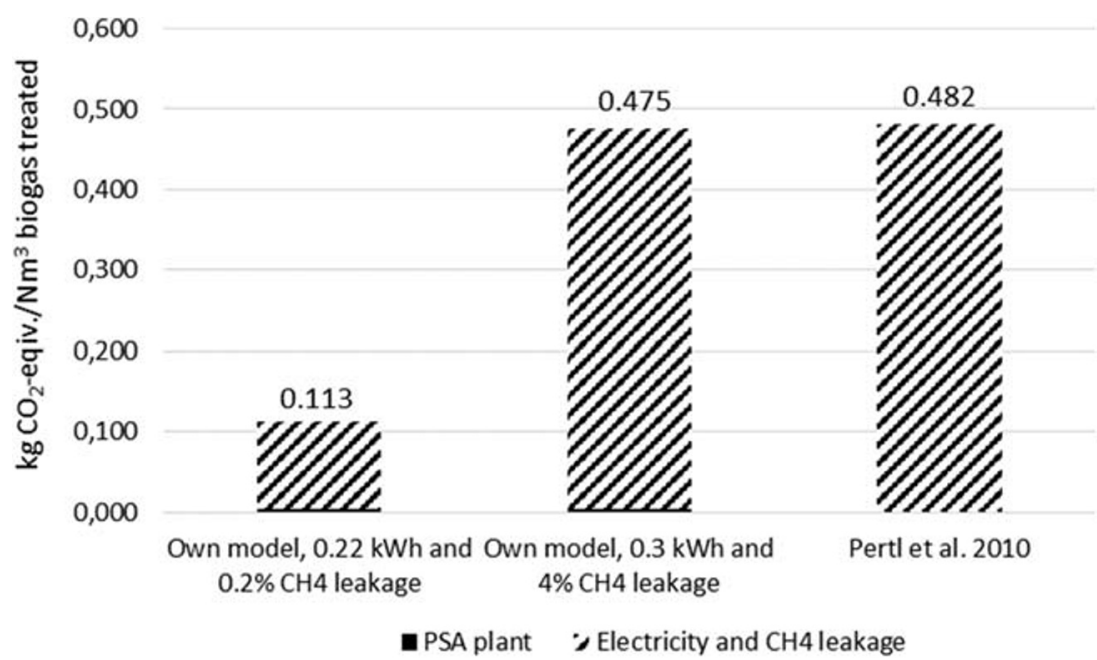

(2009) where both the CAPEX $(1,840,800 €)$ and the OPEX $\left(539,100 € /\right.$ a) of a PSA plant with a capacity of $1000 \mathrm{Nm}^{3}$ raw biogas/h were close to our calculation, although in the literature maintenance was only assessed as $2 \%$ of investment. Finally, Urban et al. (2009) calculated a total cost of 0.0647 $€ / \mathrm{Nm}^{3}$ raw biogas. Important was, however, that this literature evaluated the same technology from CarboTech®. In comparison, our results are still the most competitive: $0.05 € / \mathrm{Nm}^{3}$ raw biogas. The reason for this is that we considered the maximal possible capacity of the PSA treating $1333 \mathrm{Nm}^{3} / \mathrm{h}$ biogas. If this capacity drops by $20 \%$ to $1066 \mathrm{Nm}^{3} / \mathrm{h}$, which can easily happen due to technical disturbance or bad feed-stock qualities, the cost increases to $0.063 € / \mathrm{Nm}^{3}$ biogas treated.

\section{Conclusion}

Our study provides a detailed analysis of the PSA biogas upgrading technology considering all relevant technology steps. In our results, environmental impacts are much lower than the values found in the literature. This is mainly due to considerably lower specific electricity demands and methane leakage which was massively overestimated as an emission in the literature. Our results also reinforce the importance of electricity consumption and methane leakage of this technology because both sources induce more than 95\% of the GWP. Beside this, the main environmental impacts are MAETP and ADP induced by the indirect electricity used for producing material inputs, such as steel, plastics, and activated carbon. Thus, the use of green electricity mixes both at operation and production of input materials can considerably (by 70\%) decrease environmental burdens, and substituting coal with renewable sources for activated carbon production may further decrease potential impacts. The main environmental hotspots within the technology beside electricity consumption are induced by the creation of the general infrastructure, the $\mathrm{CO}_{2}$-removal step, and the cooling task, i.e., cold water and cooling aggregates.

The unit production cost of the PSA technology is $0.05 € / \mathrm{Nm}^{3}$ biogas treated, but its cost structure is burdened by the use of electricity taking almost $60 \%$ of all expenditures. Substantial expenses are spent on the initial investment (18\%) and personnel costs (11\%) too.

Despite our comprehensive analysis, our study has some important limitations that could be addressed in the future:

- Due to technical reasons, it was not possible to assign electricity consumption to the technology steps, and so their specific environmental burden could not be calculated.

- The methane leakage of the analyzed PSA plant was only estimated based on obligatory yearly inspections.

- Although main infrastructural units were considered, small parts, such as pipe connections, electric wires, and switches, could not be included in the inventory. Consequently, the environmental impact of the infrastructure could be larger.

Acknowledgements We would like to thank our anonymous reviewers for their valuable comments.

Funding Open Access funding enabled and organized by Projekt DEAL. This work was supported by the H2020 Framework Program EU project INCOVER, Innovative Eco-Technologies for Resource Recovery from Wastewater (Project No. 689242) and by the Helmholtz Association under the Joint Initiative "Energy System 2050-A Contribution of the Research Field Energy".

Data Availability Inventory data were collected from the company running the biogas plant and unit processes for life-cycle assessment were taken from purchased GaBi data banks.

\section{Compliance with Ethical Standards}

Conflict of Interest The authors declare that they have no conflicts of interests. 
Code Availability The GaBi9 life-cycle software (GaBi Professional perpetual Academy Seat 10,838) was used under the license purchased by the Helmholtz Centre for Environmental Research, Leipzig.

Open Access This article is licensed under a Creative Commons Attribution 4.0 International License, which permits use, sharing, adaptation, distribution and reproduction in any medium or format, as long as you give appropriate credit to the original author(s) and the source, provide a link to the Creative Commons licence, and indicate if changes were made. The images or other third party material in this article are included in the article's Creative Commons licence, unless indicated otherwise in a credit line to the material. If material is not included in the article's Creative Commons licence and your intended use is not permitted by statutory regulation or exceeds the permitted use, you will need to obtain permission directly from the copyright holder. To view a copy of this licence, visit http://creativecommons.org/licenses/by/4.0/.

\section{References}

1. Cherubini F, Strømman AH (2011) Life cycle assessment of bioenergy systems: state of the art and future challenges. Bioresour Technol 102:437-451. https://doi.org/10.1016/j. biortech.2010.08.010

2. Edenhofer O, Pichs-Madruga R, Sokona Y et al (2012) Renewable energy sources and climate change mitigation - IPCC. Cambridge University Press, Cambridge and New York

3. Scarlat N, Dallemand J-F, Fahl F (2018) Biogas: developments and perspectives in Europe. Renew Energy 129:457-472. https://doi. org/10.1016/j.renene.2018.03.006

4. Sun Q, Li H, Yan J, Liu L, Yu Z, Yu X (2015) Selection of appropriate biogas upgrading technology-a review of biogas cleaning, upgrading and utilisation. Renew Sust Energ Rev 51:521-532. https://doi.org/10.1016/j.rser.2015.06.029

5. Florio C, Fiorentino G, Corcelli F, Ulgiati S, Dumontet S, Güsewell J, Eltrop L (2019) A life cycle assessment of biomethane production from waste feedstock through different upgrading technologies. Energies 12:718. https://doi.org/10.3390/en12040718

6. Wellinger A, Baserga U, Edelmann W et al (1991) BiogasHandbuch : Grundlagen, Planung, Betrieb landwirtschaftliche Anlagen. Varlag Wirz AG, Aarau, Aarau

7. Toledo-Cervantes A, Estrada JM, Lebrero R, Muñoz R (2017) A comparative analysis of biogas upgrading technologies: photosynthetic vs physical/chemical processes. Algal Res 25:237-243. https://doi.org/10.1016/j.algal.2017.05.006

8. Adler P, Billig E, Brosowski A, et al (2014) Leitfaden Biogasaufbereitung und -einspeisung, 5., vollständig überarbeitete Auflage. Fachagentur für Nachwachsende Rohstoffe e. V. (FNR), Gülzow-Prüzen

9. Leonzio G (2016) Upgrading of biogas to bio-methane with chemical absorption process: simulation and environmental impact. J Clean Prod 131:364-375. https://doi.org/10.1016/j.jclepro.2016. 05.020

10. EUROSTAT (2019) Supply, transformation and consumption of renewables and wastes. https://appsso.eurostat.ec.europa.eu/nui/ submitViewTableAction.do. Accessed 3 Dec 2019

11. Kampman B, Leguijt C, Scholten T et al (2016) Optimal use of biogas from waste streams: an assessment of the potential of biogas from digestion in the EU beyond 2020. European Commission

12. European Biogas Association (2019) Statistical report 2019

13. Urban W, Girod K, Lohmann H (2009) Technologien und Kosten der Biogasaufbereitung und Einspeisung in das Erdgasnetz. Fraunhofer UMSICHT, Oberhausen
14. Petersson A, Wellinger A (2009) Biogas upgrading technologies developments and innovations. IEA Bioenergy

15. Angelidaki I, Treu L, Tsapekos P, Luo G, Campanaro S, Wenzel H, Kougias PG (2018) Biogas upgrading and utilization: current status and perspectives. Biotechnol Adv 36:452-466. https://doi.org/10. 1016/j.biotechadv.2018.01.011

16. Yliopisto J (2011) D5.1 - evaluation of potential technologies and operational scales reflecting market needs for low-cost gas upgrading systems

17. Bernardes MADS (2011) Biofuel's engineering process technology. BoD - Books on Demand

18. Persson M (2003) Evaluation of upgrading techniques for biogas. Evaluation of upgrading techniques for biogas

19. Pertl A, Mostbauer P, Obersteiner G (2010) Climate balance of biogas upgrading systems. Waste Manag 30:92-99. https://doi. org/10.1016/j.wasman.2009.08.011

20. Beil M, Beyrich W, Holzhammer U, Krause T (2012) Biomethan. Fachagentur Nachwachsende Rohstoffe e. V. (FNR), GülzowPrüzen

21. Sahota S, Shah G, Ghosh P, Kapoor R, Sengupta S, Singh P, Vijay V, Sahay A, Vijay VK, Thakur IS (2018) Review of trends in biogas upgradation technologies and future perspectives. Bioresour Technol Rep 1:79-88. https://doi.org/10.1016/j.biteb. 2018.01.002

22. Patterson T, Esteves S, Dinsdale R, Guwy A (2011) Life cycle assessment of biogas infrastructure options on a regional scale. Bioresour Technol 102:7313-7323. https://doi.org/10.1016/j. biortech.2011.04.063

23. Starr K, Gabarrell X, Villalba G, Talens L, Lombardi L (2012) Life cycle assessment of biogas upgrading technologies. Waste Manag 32:991-999. https://doi.org/10.1016/j.wasman.2011.12.016

24. Thrän D, Majer S, Gawor M et al (2011) Optimierung der marktnahen Förderung von Biogas/Biomethan unter Berücksichtigung der Umwelt- und Klimabilanz, Wirtschaftlichkeit und Verfügbarkeit. Deutsches Biomasseforschungszentrum gGmbH, Universität Duisburg Essen, Biogasrat e.V

25. Dewil R, Appels L, Baeyens J (2006) Energy use of biogas hampered by the presence of siloxanes. Energy Convers Manag 47: 1711-1722. https://doi.org/10.1016/j.enconman.2005.10.016

26. de Arespacochaga N, Valderrama C, Raich-Montiu J, Crest M, Mehta S, Cortina JL (2015) Understanding the effects of the origin, occurrence, monitoring, control, fate and removal of siloxanes on the energetic valorization of sewage biogas - a review. Renew Sust Energ Rev 52:366-381. https://doi.org/10.1016/j.rser.2015.07.106

27. Soreanu G, Be'land M, Falletta P et al (2011) Approaches concerning siloxane removal from biogas - a review. Can Biosyst Eng 8:18

28. Hoyer K, Hulteberg C, Svensson M, et al (2016) Biogas upgrading technical review. Energiforsk

29. Kost C, Shammugam S, Jülch V et al (2018) Levelized cost of electricity- renewable energy technologies. Fraunhofer Institute for Solar Energy Systems ISE, Freiburg, Germany

30. D'Adamo I, Falcone PM, Ferella F (2019) A socio-economic analysis of biomethane in the transport sector: the case of Italy. Waste Manag 95:102-115. https://doi.org/10.1016/j.wasman.2019.06. 005

31. Wirth H (2020) Aktuelle Fakten zur Photovoltaik in Deutschland. Fraunhofer ISE, Freiburg, Germany

32. de Hullu J, Maassen JIW, van Meel PA et al (2008) Comparing different biogas upgrading techniques. Eindhoven University of Technology

Publisher's Note Springer Nature remains neutral with regard to jurisdictional claims in published maps and institutional affiliations. 